\title{
PROSPECTIVE AND SUSTAINABILITY OF TWO NATURAL PROTECTED AREAS IN THE LEAST CROWDED STATE OF MEXICO: BAJA CALIFORNIA SOUTH
}

\author{
OSCAR ARIZPE, JUDITH JUAREZ, PLACIDO CRUZ \& ALBERTO TORRES \\ Autonomous University of Baja California South, Mexico
}

\begin{abstract}
Mexico is one of the countries with the highest levels of biodiversity in the world. Baja California South (BCS) is the Mexican state with the highest proportion of Natural Protected Areas (NPA) in its territory, the longest coastal line, and although has the lowest population density, has a highest annual population growth rate with a huge pressure from tourist development. NPA constitute fundamental instruments in the enforcement of environmental policies, essential to preserve biodiversity and are also an important engine for sustainable development. In this context the evolution of two coastal systems with almost the same age in BCS as a NPA, was analysed. The Pulmo Cape Coral Reef Area has been a rich source for many types of fishing-related activities for more than a century. Within the first three years of the study, a significant decline in the coverage of the coral reef and in the density of the fish and invertebrates was noticed, caused by the activities of the tourism and local population of the area. The NPA was officially declared in 1995 , and, up to now, the sustainable development objectives were reached, improving the quality of life of the local people and the environmental health of the reef ecosystem. The San Jose Estuary coastal wetland, located less than $100 \mathrm{~km}$ south to Pulmo Cape, was used for centuries by the local population and tourism. Their protection as an NPA was established in 1994. Results to date show a high environmental deterioration with increasing vulnerability in the last decade. The polygon of the NPA has changed 4 times in 20 years, their secular geomorphology has been reduced by more than $40 \%$ by the unplanned tourism development, initiating a big environmental deterioration that threatens the sustainable development of the contiguous population of San José del Cabo. The evaluation presents the description of these NPA, and elaborates on their importance, their major perceived challenges, and finally with an evaluation, are suggested the most favourable panoramas for the sustainable development.
\end{abstract}

Keywords: Pulmo Cape, estuary San Jose del Cabo, sustainable tourism, natural protected area management.

\section{INTRODUCTION}

The Mexican State of Baja California South is a privileged geographic region that has a natural value of great relevance both nationally and internationally, to present, among other reasons, the greater coastal extension of the Mexican Republic, also almost $50 \%$ of its area, has some decreed as Natural Protected Area (NPA), and be the one with the greatest diversity of marine resources in Mexico. This region is a biogeographic unit distinct from the rest of the country, its unique characteristics derived from its geological and natural history, has allowed the confluence of elements of arid, tropical, and temperate affinity in this region of the country, becoming for this reason be considered as the highlight tourist places in Mexico. In the Municipality of Los Cabos there are five areas for the protection and conservation of natural resources [1]. The most important are the region of Cabo Pulmo Coral Reef, and the Wetland of Estero San Jose (ESJ). 


\subsection{Estuary San José del Cabo (ESJC)}

This NPA is in the coordinates $23^{\circ} 05^{\prime} \mathrm{N}$ and $109^{\circ} 40^{\prime} \mathrm{W}$. Is also the only coastal freshwater lagoon at Baja California, bordered to the East and North with the populations of Las Animas, La Playa and La Choya, westward with the big city of San Jose of Cabo, and in the Southeast by the Gulf of California. From 1993 was declared as an Ecological State Reserve (REEESJC) (Fig. 1).

REEESJC lies in the hydrographic basin of San José del Cabo located in the southern part of the Baja California peninsula, has an area of $1,278.5 \mathrm{~km}^{2}$ and borders to the East with the Trinity Sierra and West the Sierra de la Laguna. The main channel of water that feeds the Lake is the arroyo San José, being the basin of San Jose the main source of supply of water for the towns of Cabo San Lucas and San José de el Cabo [2]. This freshwater ecosystem maintains different plant associations aquatic, underwater, riverside and growing areas, and represents an important area in the migratory route for many birds, which use it as a nesting area after completing their migration. In addition to its beauty and natural components, this region has represented from two centuries, an area of recreation for locals, and recently for the national and international tourism.

The only comprehensive study in an annual cycle in the area is the one done in 1996 [3], and just one study focused on the identification, classification and economic valuation of ecosystem services that provides this reserve to the users of the area [4], as well as the communities adjacent to the REEESJC [11]. This zone stands out for its environmental, economic, social, and cultural importance. Tradition and history of its use, were coming since the time of the indigenous, called Pericues, which has led it to be considered as of high value for the identity of the community. This ecosystem is of great relevance to the region, both from the water and biological perspective, because it provides fresh water, houses unique plant species that are part of important corridors and refuges of flora and fauna, buffer area against fires and hurricanes, conditions that have generated, all of which depends on the proper functionality of the ecosystem. It is also an area of high scenic beauty contrasting with the arid surroundings of the region, generating that for decades, has been a recreation area of local people and tourism activities of bird watching, horseback riding and boats.

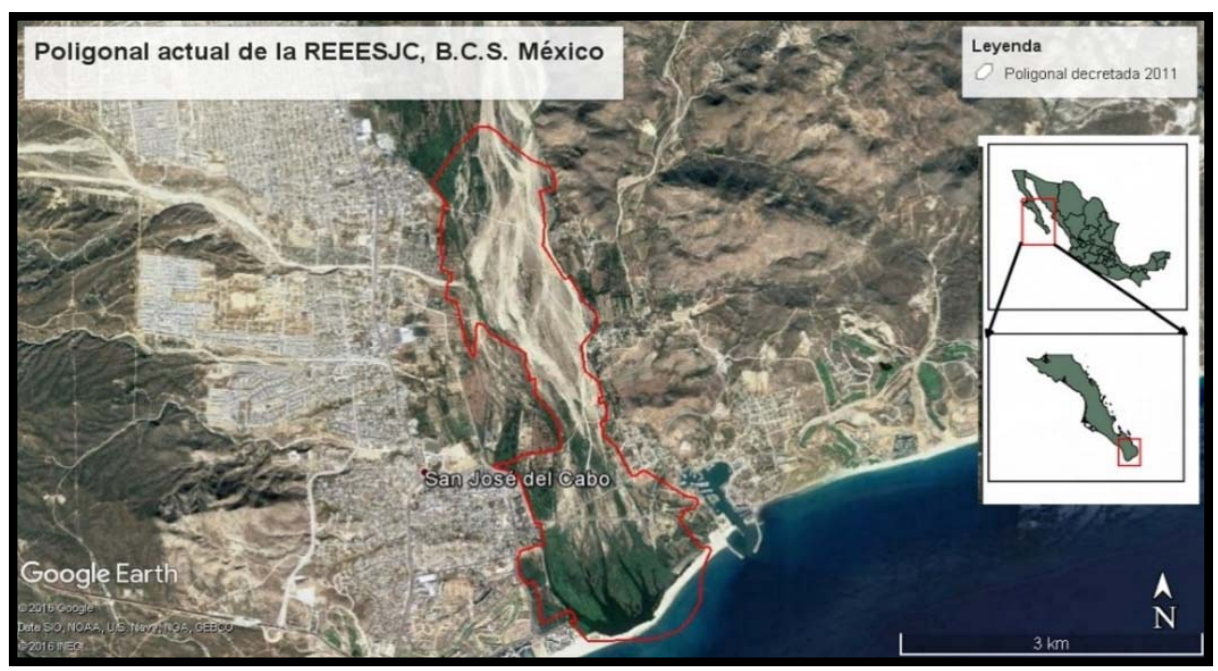

Figure 1: Localization map and the most recent polygon of REEESJC. 


\subsection{Cabo Pulmo Coral Reef}

Pulmo Cape has the most northerly coral reef in the East Pacific and the only one to be found in the Gulf of California. The beauty of coral reefs attracts an increasing number of scuba divers each year from many parts of the world. In general, submarine habitats and landscapes largely drive general tourism activities. Non-regulated development threatens the environment, making it necessary to search for strategies which help establish equilibrium between resource protection and regional development. For many years, fishing was a significant activity in Pulmo Cape which suddenly began to deplete fish stocks. One portion of Bahia Pulmo Cape and Bahia Los Frailes (an adjacent bay) have already been allocated as sites for hotels and bungalows. High impact tourism development has not yet begun, but it is imminent due to strong economic interests once the government completes paving road of the last kilometers to Cabo Pulmo. For the reef, possible disturbances include increased turbidity, altered water circulation and modifications in patterns of sedimentation. These may damage or highly modify different biotic components and reef processes (Fig. 2). Planning strategy needs to involve local people through a community-based approach, as recommended for most developing countries' reserves [5]-[7]. Research needs to address biological, socio-economic and archaeological aspects.

Properly managed and protected coral reefs may play a vital role in preserving ecosystem stability while contributing to a sustainable development. The growing importance of tourism, especially eco-tourism, as a source of employment and economic resources and to improve the health of the ecosystem, creates the possibility of an alternative to extractive activities. However, these alternatives need careful planning, evaluation, control and continual adjustment throughout its development [8]. The planning process must include the

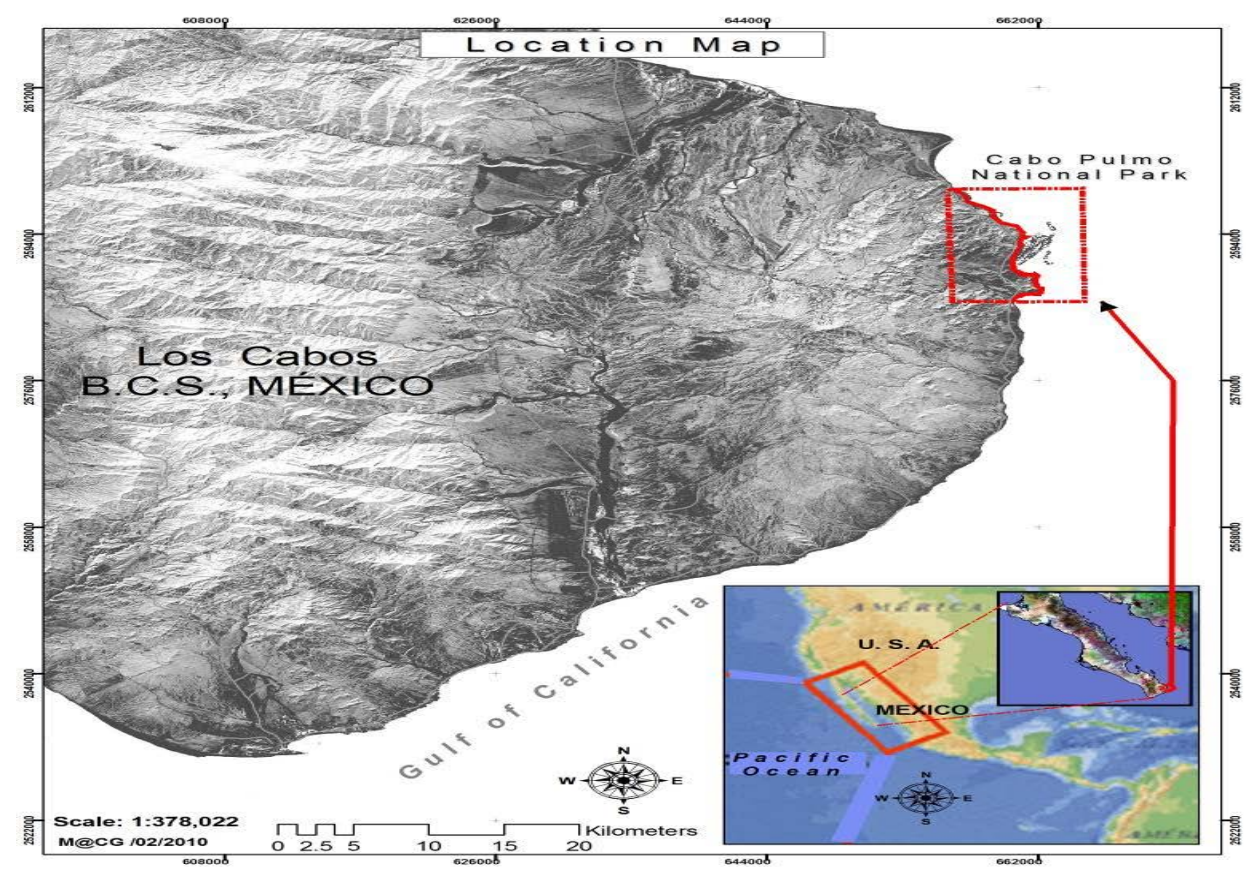

Figure 2: Cabo Pulmo Coral Reef. 
diagnosis of environmental, social and economic aspects. To achieve this goal, it is necessary a base evaluation on: 1) land capacity to withstand diverse activities, considering natural and socioeconomic interactions; and 2) potential environmental impact produced by the development of such activities [9].

\section{DIAGNOSIS}

\subsection{REEESJC}

The first official declaration as an NPA (REEESJ) was on October 8, 1993, published in the official state bulletin on January 10, 1994, with a surface area of 486.6 ha. On May 24, 2004, the State Government published a new decree of the Reserve, including the increase in the area derived from the sediment supply. On February 24, 2011, the agreement between the Government of the State of Baja California South and the City of Los Cabos was signed, so that the latter its responsible of the managing of REEESJ. Finally, in the international sphere, the ESJ is incorporated on February 2, 2008, as an Area of Importance for the Conservation of Birds at the national level under the category G1 and finally in 2009 was registered in the RAMSAR [10] international wetland system.

From ten years ago, in various conferences and diverse kind of meetings it has been mentioned that restoration of the ESJ is urgently, needed because it is in the process of deterioration, which was ratified with its analysis and discussion at the "National Forum for Sustainable Coastal Development" (November 2014). Because of this agreement, they were carried out with broad participation of all levels of government, NGOs, academic institutions, and users, with a focus on the entire management of the San José Basin (SJB). More recently in the years 2015 and 2016 there have been several workshops highlighting that perhaps the most important problem is the alteration and change since 2003, of its geomorphology, generated by the almost complete disappearance of the north arm that borders of the NPA wetland, produced by Puerto Los Cabos tourism development, which has reduced its stability, increasing the risks of irreversible alteration of the entire riparian ecosystem. Likewise, other adverse factors such as the changes in the area and the change in land use in the boundaries of the natural area polygon due to the urban growth of San José del Cabo city, due to the erosion of the SJB, have been added. To the impact of human activities (opening of roads, extraction of forest species and livestock), establishing that the magnitude of the effect of all these factors could not be known with existing information, because the baseline information of ecological attributes and integral characterization of the system [3] is outdated from 1996.

Diagnosis of the study area was elaborated based on the literature and Geographic Information Systems (GIS) digital data bases and electronic resources available, some of the documents consulted, refer to the physical and biological characteristics at the basin level [10], [11]. Others refer to the characteristics of the area at the municipal level, environmental impact assessment (EIA), works of channeling or protection of watercourses, however, also some study [12] which describes specific both biological and physical elements within the area, mainly those related to the body of water, however the information collected in these works was not referenced or does not correspond to the coordinates that define the current management policies.

In the last 15 years, there have been many changes in the REEESJC geomorphology, including several amendments in the legal framework in chronological order as follows: On October 1993 is decreed the area of estero de San José de el Cabo as State Ecological Reserve, modifying the 10 January 1994 is category to ecological conservation zone category. In 2003 the northern arm was completed damaged. In 2004, on the 24th of May, the surface of the 
polygon is modified leaving it with a total of 512.2 has. April 4th, 2011, again modifying the polygon of the REEESJC staying up to date with an area of 766.7 has. The main problems evidenced to cause extensive modifications and negative effects in the area is the growth of the human population, who from 1990 to 2010 is has quadruplicate (a rate of $455 \%$ ) in just 20 years, and the environmental impact of tourism development described formerly.

\subsubsection{Pulmo Cape}

We started the environmental research and the description of the structure of the community of the coral reef in 1987. Focusing on the study of density and diversity of the coral species, equinoderms, mollusc and fish, we realized that all this species were decreasing caused by intensive fishing. Pulmo Cape is the oldest known coral reef in the American Pacific, with its age being estimated at 25,000 years [13], in contrast to 5000-5500 years for Panamanian reefs [14]. There are some paleontological remains of reef fauna at a Pleistocene marine terrace dated to $125 \mathrm{k} . \mathrm{a} . \pm 1000$ years. The reef biota is diverse and from four different bio geographic provinces: Panamic, Californian, Cortezian, and Indo-Pacific [15]. Pulmo Cape reef was first described by the scientific community in the classic papers of Steinbeck and Ricketts [16], Squires [13] and Brusca and Thomson [17], who highlighted its importance as a special and unique ecosystem in the Gulf of California. The El Niño Southern Oscillation (ENSO) effect of 1982-1983, which almost destroyed the Pacific reefs of Galapagos, Costa Rica and Panama, was not apparent in Pulmo Cape. The main components of the terrestrial flora are xeric scrublands, scrub and grassland [18]. The fauna is rich and diverse, with outstanding terrestrial mammals, seasonal arrival of marine and coastal birds, and of sea turtles of which some are considered threatened or in danger of extinction.

All these plants and animals alone could be potential resources for nature tourism, for instance, their observation would assist their conservation and provide economic benefits for the local people. One small settlement is in the area with a population of 200 people. Until 1991, the economics of Pulmo Cape people was based mainly on artisanal fishing with the addition of $20 \%$ agriculture. However, nowadays sustainable tourism activities play the most important role and consist of snorkeling and scuba diving, camping, hiking, mule treks and bicycling. Most of these activities have been developed by foreign people, mainly from The United States and Canada [19]. Tourism facilities consists of restaurants, bungalows, one resort and scuba diving services. Along the coast of Bahía Pulmo Cape, there are also archaeological remains belonging to Pericues tribes which inhabited the area during precolonial and the beginning of Spaniard colony times. The resident human population comprises mainly fishing families that have lived there for generations and some foreigners. Currently, the number of visitors is growing, and this rate will be higher in the short period of time due to imminent completion of a paved road from the main highway.

Several management goals and objectives for long-term management of area were recognized: (1) To preserve the coral reef, its components, associated habitats and biotic communities; (2) To preserve ecological processes and life support systems; (3) To maximize economic and social benefits from the area; (4) To promote conservation compatible uses; and (5) to promote environmental education between general public and research initiatives. This proposal led to Pulmo Cape reef being declared a protected zone by the Mexican government on June 5, 1995, under the category of National Marine Park.

Nowadays the main economic potential of Pulmo Cape Park is of a recreational character, focused almost exclusively on aquatic activities such as snorkeling and scuba diving. Workshops and consult-meetings were developed from 1991 to 1995 to discuss the environmental damage, initial plans to recommended management actions, permitted uses, prohibited activities and problems of each of the environmental units generated in the zoning 
process of Pulmo Cape. The first proposed scheme is shown in Fig. 3, (more than ten years before management plan was decreed in 2010), which integrates the environmental policies and each unit use capacity. Because of seasonal variations in weather conditions, the area allows the realization of more than one activity in several units. In general, this will mean no conflict for space or resource. The areas with a certain degree of modification present high capacity for all the tourism activities. The mountain areas have a medium capacity for camping, hiking and mule treks, while the suitability for bicycling is low. Units close to the coast line are considered recreational areas and camping, swimming and snorkeling can be done. In general, low impact activities are proposed, balancing the use of natural resources with continuous economic growth [21].

The marine areas have a great capacity for water sports, especially underwater tourism focusing on the coral reefs. Scuba diving is now very popular on Pulmo Cape coral reefs for divers from all over the world. The strategic plan for conservation of the coral reef ecosystem developed in 1996, with the community consult and involvement, was detailed focused for scuba diving on the coral reefs has been proposed with the design of a mooring buoys scheme, the forbidding of anchoring directly on reef areas and implementation of a plan of use for each specific site with strict regulations of the number and type of scuba divers. With this plan in effect, only the best qualified divers (dive masters) could use some of the most vulnerable sites, and the less qualified (open water divers) other selected reef sites with lower values of vulnerability (Fig. 4). Considering this is the most important activity in the National Park, many workshops have been taking place to communicate and correction of the plan and to agree all the details to its implementation.

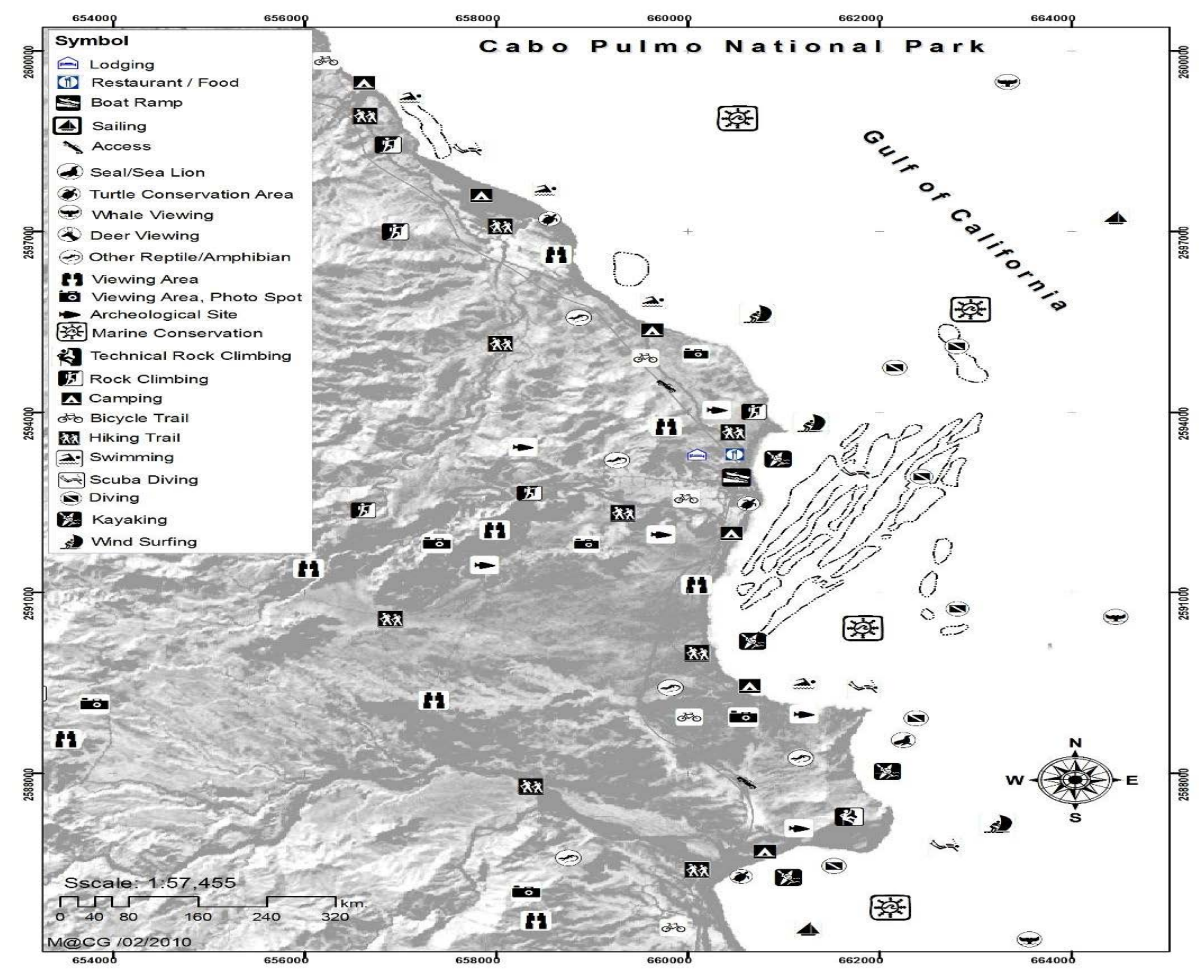

Figure 3: Sustainable tourism activities scheme [21]. 


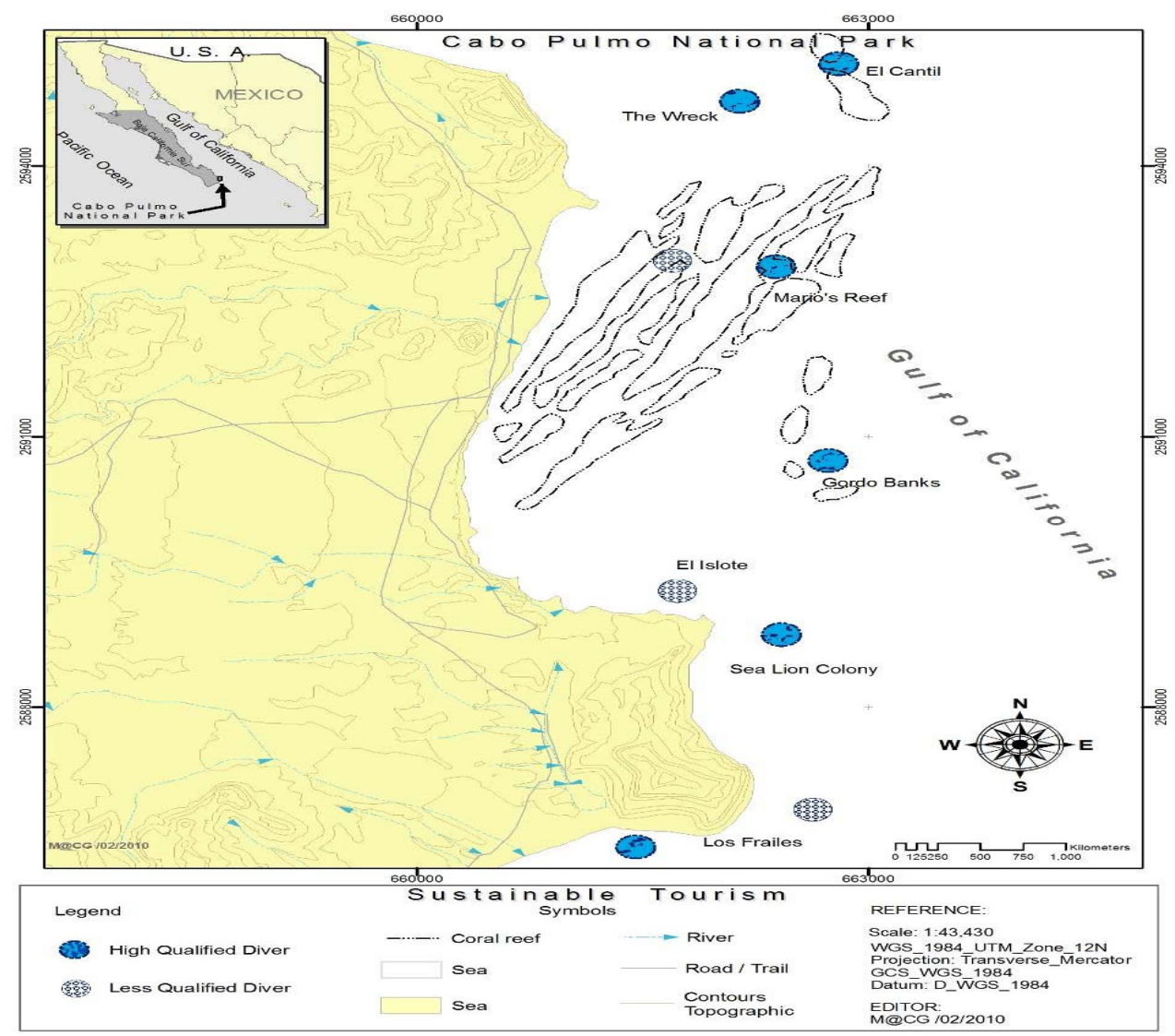

Figure 4: Conservation plan for the NPA, with scuba diving scheme [21].

\section{DISCUSSION}

Although creation and management of natural reserves is the most widely used, experience has shown protection is not the complete solution. It should be noted that the application of GIS in the present proposal, identifies key issues for the implementation of the management plan of both study areas. In the case of San Jose Estuary, unfortunately, the recent status of the wetland has increased the vulnerability of the REEESJC and on surrounding population, specially to dangerous environmental events, like eutrophication processes, pollution, and fires. The natural homeostasis of the integral ecosystem who possibilities to be a natural buffer to a natural disaster, has been lost for the geomorphology damage, producing a more fragile and vulnerable system, and unfortunately the local community and specially the authorities, few actions had been developed to solve the problems. As a resume of the geomorphological changes of the wetland in the last 15 years. Integral determinations of fragility, pressure, and final evaluation of vulnerability [20], allow to know the current state of the system, becoming an important tool for the decision makers for the generation of program management with an important restoration component. Finally considering the loss of original geomorphology, as a highly relevant ecosystem, it is important the get the involvement of authorities to implement an urgent study and Restauration Plan of the wetland 
of REEESJC, to prevent irremediable damages not just for the environment, also the tourism and the local population, with the increment for example of floods, fires, pollution, of this relevant ecosystem not just for Baja California Peninsula.

The creation of the protected area is just one of steps of management, but some regulations were expected to be started even before the design of the reserve. That is the case for Cabo Pulmo, the first phase of the management strategy, was carried out by a research institution (Autonomous University of Baja California South) and local residents more than 10 years the official management plan was decreed. That strategy included the subsequent management programs: (1) the management plan elaboration, (2) an environmental education program for residents and visitors, (3) the setting up of mooring buoy systems for recreation and scuba diving zones, (4) a monitoring program for environmental factors and benthic surveys, and (5) the financial assistance searching [21]. This phase encompassed all immediate resource-use conflicts and includes the establishment of programs of zoning, vigilance, law-enforcement, public education, defining of research priorities and financial assistance. Because all groups involved should participate in decision making, the major administrative structure in the reserve must be a council formed by representatives of residents, tourism workers, educational and research centers, and government agencies.

Finally, this shows that the enforcement system should be based on local residents, research institutions, and tourism companies supported by the respective authorities. This stage of the process is where most of the protected areas of Mexico have met their biggest problems, sometimes so difficult to overcome that management plans are almost useless or never applied. That is the case of REEESJC, which is gradually more human damaged, generating as we described before, a lot of problems. Fortunately, in Pulmo Cape, after more than 20 years within this coralline system as a National Park, has demonstrated good environmental conditions and a wealthier local population. The quality of life of the inhabitants has increased, within a healthier ecosystem, along with the recovery of coral, many sea turtles, sharks, other fish, and invertebrate populations. This success was achieved with the collaboration of the local people, and nowadays with government agencies and all sectors involved. The ideal of a well-managed, self-sustainable marine reserve is been achieved. The natural system is getting better, and the local people has increased their quality of life. The change in approach of the Pulmo Cape population, from traditional fishing to sustainable tourism services, has created something more profitable than fishing, and the coralline ecosystem is recovering and getting better each year.

\section{REFERENCES}

[1] Arizpe, A. \& Bermudez B., Prospective de the Natural protected areas of Los Cabos. Los Cabos, Prospective for a Natural and Tourism Paradise, eds P. Ganster, O. Arizpe \& A. Ivanova, San Diego University: California, pp. 125-154, 2012.

[2] Arizpe, O. \& Arizpe, M., Prospective of the Natural protected areas of the south of Baja California Peninsula. Management of Natural Resources, Sustainable Development and Ecological Hazards IV, ed. C.A. Brebbia, WIT Press: Boston, pp. 35-45, 2015.

[3] Universidad Autónoma de Baja California Sur., Caracterización Ambiental de la Reserva Ecológica Estatal "Estero de San José”, Universidad Autónoma de Baja California Sur: México, pp. 149, 1996.

[4] Arizpe, O., Armenta, L. \& Olmos, E. (in press), El humedal prioritario de Baja California South: Servicios Ecosistémicos. U.A.B.C. Press: Mexico.

[5] White, A.T., Marine Parks and Reserves: Management for Coastal Environments in Southeast Asia, ACLARM Education Series 2: Philippines, pp. 33, 1988. 
[6] White, A.T., The effect of community-managed marine reserves in the Philippines on their associated coral reef fish population. Asian Fisheries Society, 1(2), pp. 27-42, 1988.

[7] White, A.T. \& Palaganas, V.P., Philipine Tubbataha Reef National Marine Park: Status, management issues, and proposed plan. Environmental Conservation, 18(2), pp. 148-157, 1991. DOI: 10.1017/s0376892900021731.

[8] Arizpe, O., Fermán, J., Rivera, R., Ramírez, J. \& Rodríguez, R., Evaluation and land use planning process of a high population growth rate municipality: Los Cabos, Mexico, Environmental Economics and Investment Assessment I, eds K. Aravossis, C.A. Brebbia \& N. Gomez, WIT Press: Boston, pp. 87-96, 2008.

[9] Secretaria de Medio Ambiente y Recursos Naturales, Ley General del Equilibrio Ecológico y Protección al Ambiente, Delma: México, pp. 114, 1996.

[10] Secretaría de la Convención de Ramsar, Manual de la Convención de Ramsar: Guía a la Convención sobre los Humedales (Ramsar, Irán, 1971), Secretaría de la Convención de Ramsar: Suiza, pp. 116, 2013.

[11] Armenta, L.F., Propuesta de programa de manejo para la reserva ecológica estatal Estero de San José., Tesis de Maestría en Ciencias. Universidad Autónoma de Baja California Sur: México, pp. 204, 2015.

[12] National Assessment of Coastal Vulnerability to Sea-Level Rise: Preliminary Results for the U.S. Pacific Coast; United States Geological Survey. Online. https://woodshole.er.usgs.gov/project-pages/cvi/ofr.html. Accessed on: 17 May 2018.

[13] Squires, D.F., Corals and coral reefs in the Gulf of California. Bulletin of the American Museum of Natural History, 118, pp. 371-431, 1959.

[14] Glynn, P.W. \& McIntyre, I.G., Growth rate and age of coral reefs on the Pacific coast of Panama. Proceedings of the Third International Symposium of Coral Reefs, pp. 251-259. 1977.

[15] Reyes-Bonilla, H., 1993, Estructura de la comunidad, influencia de la depredación y biología poblacional de coral hermatípicos en el arrecife de Pulmo Cape, Baja California South. Tesis de Maestría. Centro Interdisciplinario de Estudios Superiores de Ensenada. Ensenada Baja California. México, pp. 169, 1977.

[16] Steinbeck, J. \& Ricketts, E.F. (eds), Sea of Cortez, Viking Press: New York, pp. 598, 1941.

[17] Brusca, R.C. \& Thomson, D.B., Pulmo reef: The only "coral reef" in the Gulf of California. Ciencias Marinas, 2(2), pp. 37-53, 1975.

[18] López-Espinosa de los Monteros, R., Propuesta de Ordenamiento de las Actividades de la Zona Marina de Loreto, B.C.S., México. Tesina de Especialidad, UABC, Ensenada, B.C., México, pp. 56, 1996.

[19] Proyecto Mar de Cortés, México Fondo Nacional de Fomento al Turismo. Online. www.fonatur.gob.mx/es/index.asp. Accessed on: 17 May 2018.

[20] Arizpe, O., Juarez, J., Cruz, P. \& Torres, A., Evolution of a coastal oasis in a high population growth rate municipality: Los Cabos, México. International Journal of Sustainable Development and Planning, 13(4), pp. 605-613, 2018.

[21] Arizpe, O., Prospective and planning strategy for the northern most coral reef of Eastern Pacific: Cabo Pulmo. Gulf of California, Tourism and Environment, ed. E. Pineda, WIT Press: Boston, pp. 59-74, 2014. 